Article

\title{
In Vitro Effects of Paralytic Shellfish Toxins and Lytic Extracellular Compounds Produced by Alexandrium Strains on Hemocyte Integrity and Function in Mytilus edulis
}

\author{
Virginia Angélica Bianchi ${ }^{1, *}$, Ulf Bickmeyer ${ }^{2}$, Urban Tillmann ${ }^{2}{ }^{(D}$, Bernd Krock $^{2}$, Annegret Müller ${ }^{2}$ \\ and Doris Abele ${ }^{2, *}$ \\ 1 Laboratorio de Ecotoxicología Acuática, INIBIOMA (CONICET-UNCo)—CEAN, Ruta Provincial Nº 61, \\ Km 3, CCP 7, Junín de los Andes, Neuquén 8371, Argentina \\ 2 Alfred Wegener Institute for Polar and Maine Research, Am Handelshafen 12, 27570 Bremerhaven, Germany; \\ ulf.bickmeyer@awi.de (U.B.); urban.tillmann@awi.de (U.T.); bernd.krock@awi.de (B.K.); \\ annegret.mueller@awi.de (A.M.) \\ * Correspondence: vabianchi@comahue-conicet.gob.ar (V.A.B.); Doris.Abele@awi.de (D.A.)
}

check for updates

Citation: Bianchi, V.A.; Bickmeyer, U.; Tillmann, U.; Krock, B.; Müller, A.; Abele, D. In Vitro Effects of Paralytic Shellfish Toxins and Lytic Extracellular Compounds Produced by Alexandrium Strains on Hemocyte Integrity and Function in Mytilus edulis. Toxins 2021, 13, 544. https:// doi.org/10.3390/toxins13080544

Received: 18 June 2021

Accepted: 29 July 2021

Published: 5 August 2021

Publisher's Note: MDPI stays neutral with regard to jurisdictional claims in published maps and institutional affiliations.

Copyright: (c) 2021 by the authors. Licensee MDPI, Basel, Switzerland. This article is an open access article distributed under the terms and conditions of the Creative Commons Attribution (CC BY) license (https:/ / creativecommons.org/licenses/by/ $4.0 /)$.
Abstract: Harmful effects caused by the exposure to paralytic shellfish toxins (PSTs) and bioactive extracellular compounds (BECs) on bivalves are frequently difficult to attribute to one or the other compound group. We evaluate and compare the distinct effects of PSTs extracted from Alexandrium catenella (Alex5) cells and extracellular lytic compounds (LCs) produced by A. tamarense (NX-57-08) on Mytilus edulis hemocytes. We used a $4 \mathrm{~h}$ dose-response in vitro approach and analyzed how these effects correlate with those observed in a previous in vivo feeding assay. Both bioactive compounds caused moderated cell death (10-15\%), being dose-dependent for PST-exposed hemocytes. PSTs stimulated phagocytic activity at low doses, with a moderate incidence in lysosomal damage (30-50\%) at all tested doses. LCs caused a dose-dependent impairment of phagocytic activity (up to 80\%) and damage to lysosomal membranes (up to 90\%). PSTs and LCs suppressed cellular ROS production and scavenged $\mathrm{H}_{2} \mathrm{O}_{2}$ in in vitro assays. Neither PSTs nor LCs affected the mitochondrial membrane potential in hemocytes. In vitro effects of PST extracts on M. edulis hemocytes were consistent with our previous study on in vivo exposure to PST-producing algae, while for LCs, in vivo and in vitro results were not as consistent.

Keywords: neurotoxins; bioactive extracellular compounds; immune response; blue mussel

Key Contribution: PSTs extracted from Alexandrium catenella (Alex5) stimulate phagocytic activity in hemocytes at low doses and cause limited cellular damage, while LC containing supernatant from A. tamarense (NX-57-08) is immunotoxic and cytotoxic. Both fractions, i.e., PST cellular extract and culture supernatant with LCs act as antioxidants in extracellular $\mathrm{H}_{2} \mathrm{O}_{2}$ production and in vitro $\mathrm{H}_{2} \mathrm{O}_{2}$ scavenging assays.

\section{Introduction}

Dinoflagellate species of the genus Alexandrium are responsible for harmful algal blooms (HAB) affecting marine ecosystems, with massive socio-ecological consequences resulting worldwide [1-3]. Alexandrium spp. can produce different types of toxic or harmful bioactive compounds, with reported deleterious effects on the aquatic fauna, including commercially interesting species of fish and bivalves [3]. In this context, HAB exposure has been related to altered immune functions and global physiological distress, producing increased susceptibility to diseases in bivalves [4]. An unambiguous attribution of the harmful effects to one or another compound group remains, however, difficult.

One important group of compounds produced by a number of Alexandrium species are paralytic shellfish toxins (PSTs). PSTs have been known for more than 70 years [5], are chemically well-characterized [6], and their mode of action as blockers of sodium ion channels 
in vertebrate nerve cells has been elucidated (reviewed in [7]). In contrast, little is known about their biological role. The PST group includes the highly neurotoxic saxitoxin (STX) as well as its variants such as neosaxitoxin (NEO), gonyautoxins1-4 (GTX1-GTX4), and the $\mathrm{N}$-sulfocarbamoyl PST variants called B1/2 and C1-4 toxins [8]. All of these compounds are not readily released into seawater by intact cells [9]; instead, Alexandrium cells are consumed by algal grazers such as filter-feeding bivalves, and toxins are released from the algae into the animal's digestive tract. Even though invertebrates are much more tolerant to phycotoxins than vertebrates, including marine mammals and humans, exposure to a HAB of Alexandrium spp. may still produce neurotoxic and/or cytotoxic effects in bivalves, which cause tissue damage, paralysis, altered behavior, loss of coping strategies, and mass mortalities (reviewed in [3]). During the feeding process, the immune defense system, gut microbiota, and physiological mechanisms of toxin biotransformation allow bivalves to metabolize, accumulate, and/or eliminate PSTs, e.g., [10,11]. Part of the defense against toxic algae involves the hemolymphatic cellular immune response, also involved in xenobiotic metabolism and tissue regeneration processes [12,13]. Administration of PST-producing algae, pure single PST, or a mix of these toxins can also trigger immunological responses in clams $[9,14,15]$, oysters [16,17], and mussels [18]. However, whether PSTs produce immunotoxic or immunostimulant effects on bivalves depends on the species' resistance, their toxin exposure history, and the ingested doses. In particular, Mytilus spp. display a high level of immunological vigor toward adverse environmental conditions compared to other marine bivalves [19]. Galimany et al. [20] suggest that PSTs spread throughout the hemocyte cytoplasm and accumulate in lipofuscin granules in order to be eliminated in the intestinal lumen. In addition, immunological modulation involving hemocyte mobilization, phagocytic activity, reactive oxygen species (ROS) production, antioxidant responses, and reduced cellular viability were observed in PST-exposed mussels $[18,20,21]$.

Many species of Alexandrium, including many of the PST-producing ones, also produce bioactive extracellular compounds (BECs), which are clearly unrelated to the known PSTs [22]. In contrast to PSTs, BECs are released to the surrounding aquatic medium [9,23], where they inhibit the growth and survival of competing algae and protistan grazers [24,25]. In contrast to their well-documented biological functions and ecological effect, the chemical nature of BECs is poorly characterized. Particularly, the production of BECs with lytic activity (Lytic compounds, LCs) was shown for Alexandrium. These LCs are large amphipathic compounds (between 7 and $15 \mathrm{kDa}$ ) that do not belong to any group of known biopolymers such as peptides or polysaccharides [26]. Their lytic activity is stable over wide ranges of temperatures and $\mathrm{pH}$ and are refractory to bacterial degradation, but these compounds generally show low recovery in common purification techniques [27].

Growing evidence documents the effect of BECs on the immunological functions of bivalves exposed to LC-producing algae, e.g., [28-31]. Particularly, the mechanisms of action of LCs include the disturbance of cell membrane integrity, with some indications that contact between LCs and certain sterol molecules in the membranes are involved [23]. In vitro immunotoxic effects of Alexandrium strains that do not produce PSTs were evidenced to diminish phagocytic activity and surface cellular adherence in hemocytes of two clam species, which was attributed to the hypothetical action of LCs on cellular osmotic balance [8]. It has further been suggested that the direct cytotoxic effect of LCs on hemocytes occurs when: (i) hemocytes infiltrate the gill tissue and intestinal lumen of the bivalves and get in contact with LCs and/or producer algae, and (ii) when hemocytes get in contact with LCs containing seawater that infiltrates the open circulatory system of the bivalves $[9,29,30]$.

Whereas numerous studies on the physiological effects of PSTs in bivalves exist, similar studies dealing with BECs are scarce. However, in both cases, studies are mostly focused on in vivo assays, while in vitro assays are scant. Furthermore, many studies investigating the effects of PSTs use Alexandrium cultures in which the possible effect of BECs is not evaluated, and thus cannot differentiate between the effects of both compound classes, and/or attribute the effects only to PSTs. In Bianchi et al. [31], we showed that 
feeding Mytilus edulis with PST and/or LC-producing Alexandrium strains (Alex5 and Alex NX-57-08, respectively) caused similar rates of hemocyte damage and immune function impairment after three days. These effects were mostly transitory, vanishing within a seven-day experimental period, with the exception of lysosomal membrane damage that accrued when PSTs and LCs were combined. However, PST amounts and LC activity differed among algal strains used in this in vivo exposure, which implies some difficulty in interpreting and comparing individual and combined effects. Therefore, additional in vitro experiments were conducted to evaluate how hematological effects in M. edulis relate to the action of each algal toxin type on the hemocytes, and how these effects correlate with those observed in vivo. Increased knowledge of the physiological responses and deleterious effects of bioactive compounds from dinoflagellates on bivalves, integrating in vivo and in vitro approaches, may help to explain their mechanisms of action and predict further consequences in the field. The aim of this work was to evaluate and compare the distinct effects of PST extracts and lytic culture supernatant (extracellular LCs) produced by Alexandrium strains (Alex5 and Alex NX-57-08, respectively) on hemocyte integrity and immune function, using a dose-response in vitro approach. In addition, a comparative assessment of present in vitro and previously published in vivo results is discussed.

\section{Results}

\subsection{PST and LC Effects on Hemocytes \\ 2.1.1. Cytotoxicity}

No significant effect on the cellular count was detected after $4 \mathrm{~h}$ of treatment with PST or LC doses (ANOVA $p=0.36$ and $p=0.18$, respectively). Exposure of M. edulis hemocytes to extracted PSTs elicited a dose-dependent effect on cell viability (exponential function: Viability $=93.74 \mathrm{e}^{(-0.0019 \mathrm{x})}, \mathrm{S}=1.98 ; \mathrm{EC}_{50} 67.54 \mu \mathrm{M}$ PST, corresponding to 373 A. catenella cells $\mathrm{mL}^{-1}$; CI 95\%: 192 to 852 ), with a maximal diminution of $15 \%$ viability. Viability was significantly affected (ANOVA $p<0.01$ ) at $125-500 \mu \mathrm{M}$ (corresponding to $690-2760$ A. catenella cells $\mathrm{mL}^{-1}$ ) (Dunnett's test $p<0.05$ ), with an additional effect at the highest concentration $\left(1250 \mu \mathrm{M}\right.$, corresponding to 6900 A catenella cells $\mathrm{mL}^{-1}$, Dunnett's test $p<0.01$ ) compared to control (Figure 1a). Exposure to LCs also resulted in $10-15 \%$ loss in cell viability when hemocytes were exposed to culture supernatant from 340 to 6800 A. tamarense cells $\mathrm{mL}^{-1}$ compared to control (ANOVA $p<0.001$; Dunnett's test $p<0.01$ for 340 and 1700 cells mL $\mathrm{mL}^{-1} ; p<0.001$ for 680 cells mL ${ }^{-1} ; p<0.05$ for 3400 and 6800 cells $\mathrm{mL}^{-1}$ ) (Figure 1b). Lysosomal membrane stability decreased by $30-50 \%$ compared to control level upon exposure to all PST concentrations (ANOVA $p<0.01$; Dunnett's test $p<0.05$ ) (Figure 1c). For LCs, this marker decreased in a dose-dependent manner (exponential function: Lysosomal membrane stability $=0.019 \mathrm{e}^{(-0.0025 \mathrm{x})}, \mathrm{S}=0.002$; $\mathrm{EC}_{50} 274$ A. tamarense cells $\mathrm{mL}^{-1}$; CI 95\%: 153-1345) and by almost $90 \%$ in cells exposed to the exudate from the highest algal cell densities (ANOVA $p<0.05$; Dunnett's test $p<0.5$ for 170 cells mL $\mathrm{mL}^{-1} ; p<0.01$ for 340 and 680 cells $\mathrm{mL}^{-1} ; p<0.001$ for $1700-6800$ cells $\mathrm{mL}^{-1}$, compared to control) (Figure 1d).

\subsubsection{Cellular Function}

Phagocytic activity changed with increasing PST concentration to a maximum in the 62.5 and $125 \mu \mathrm{M}$ treatments corresponding to 345 and 690 A. catenella cells $\mathrm{mL}^{-1}$ (ANOVA $p<0.001$; Dunnett's test $p<0.01$ for both), without further changes at higher concentrations with respect to control (Figure 2a). LCs impaired phagocytosis in a dose-dependent manner (exponential function: Phagocytic activity $=0.64 \mathrm{e}^{(-0.0033 \mathrm{x})}, \mathrm{S}=0.07 ; \mathrm{EC}_{50} 211$ A. tamarense cells $\mathrm{mL}^{-1}$; CI 95\%: 125-683). At the highest doses, phagocytic activity was $80 \%$ lower than in controls (ANOVA $p<0.0001$; Dunnett's test $p<0.05$ for 170 cells $\mathrm{mL}^{-1} ; p<0.01$ for 340 and 680 cells $\mathrm{mL}^{-1} ; p<0.001$ for $1700-6800$ cells $\mathrm{mL}^{-1}$ ) (Figure $2 \mathrm{~b}$ ). 
PST

(a)

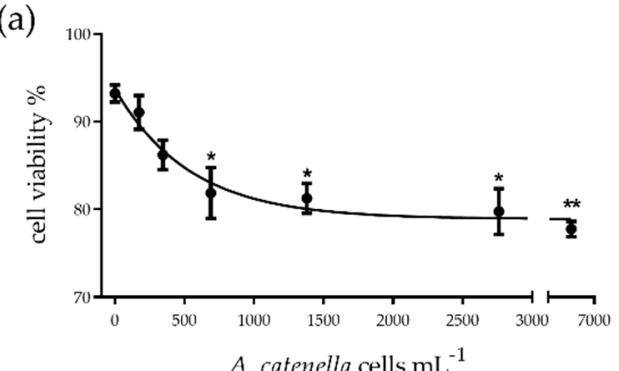

(c)

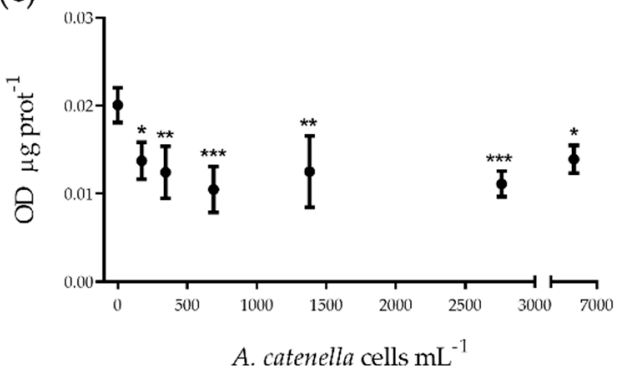

LC

(b)

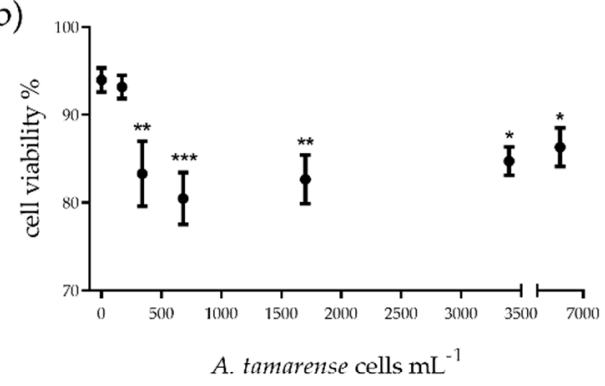

(d)

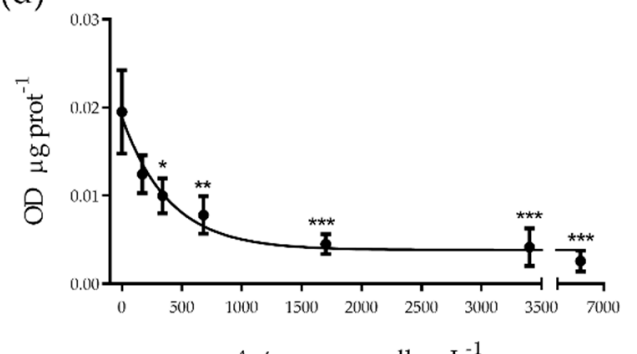

Figure 1. (a,b) Cellular viability and (c,d) lysosomal membrane stability of Mytilus edulis hemocytes exposed in vitro to paralytic shellfish toxins (PSTs)or to extracellular lytic compounds (LCs) from Alexandrium strains (Alex5 and Alex NX-57-08, respectively). PST and LC concentrations are expressed as the equivalent number of Alexandrium spp. cells $\mathrm{mL}^{-1}$. Results are presented as mean \pm SEM. Asterisks denote significant differences between an individual treatment and the control $\left({ }^{*} p<0.05 ; * * p<0.01 ; * * *<0.001\right), n=4(\mathbf{c}, \mathbf{d})$, pooled hemolymph from two mussels and $n=5(\mathbf{a}, \mathbf{b})$, individual mussels per treatment.

(a)

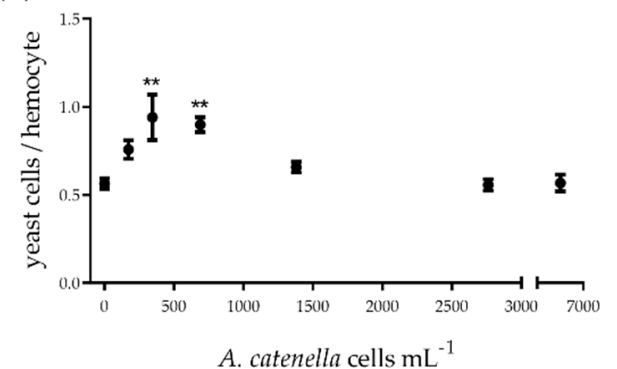

(b)

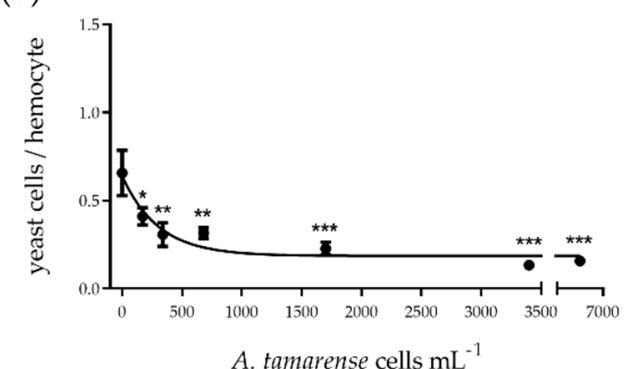

Figure 2. Phagocytic activity of Mytilus edulis hemocytes exposed in vitro to (a) PSTs or to (b) extracellular LCs from Alexandrium strains (Alex5 and Alex NX-57-08, respectively). PST and LC concentrations are expressed as the equivalent number of Alexandrium spp. cells $\mathrm{mL}^{-1}$. Results are presented as mean \pm SEM. Asterisks denote significant differences between an individual treatment and the control $\left({ }^{*} p<0.05 ; * *<<0.01 ;{ }^{* * *} p<0.001\right), n=5$ mussels per treatment.

Hemocyte extracellular $\mathrm{H}_{2} \mathrm{O}_{2}$ production decreased by about $60 \%$ in all PST treatments compared to control (ANOVA $p<0.001$; Dunnett's test $p<0.001$, for all comparisons) (Figure 3a). The effect of LC containing the supernatant on hemocytes diminished extracellular $\mathrm{H}_{2} \mathrm{O}_{2}$ levels only for 680 and 3400 A. tamarense cells mL $\mathrm{m}^{-1}$ (ANOVA $p<0.05$; Dunnett's test $p<0.01$ and $p<0.05$, respectively) (Figure $3 \mathrm{~b}$ ). Intracellular ROS formation was affected only at the highest exposure concentration and diminished by $30 \%$ for both PST and LC exposure compared to control (ANOVA $p<0.05$; Dunnett's test $p<0.05$, for both comparisons) (Figure $3 c, d$ ). 
PST

(a)

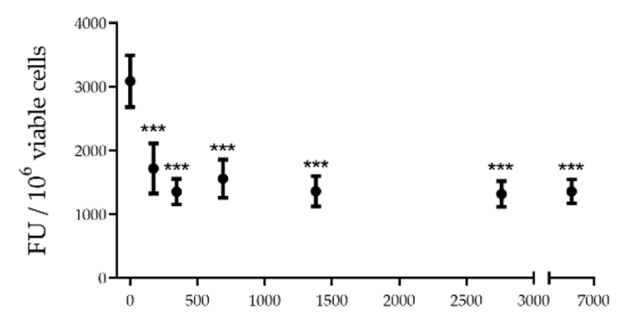

(c)

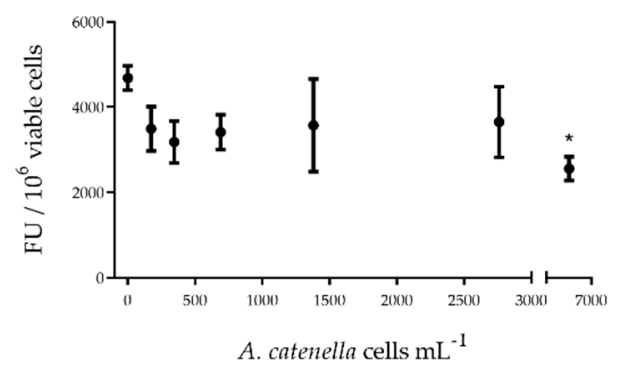

LC

(b)

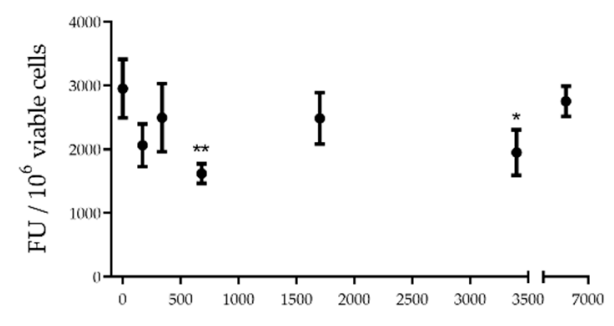

(d)

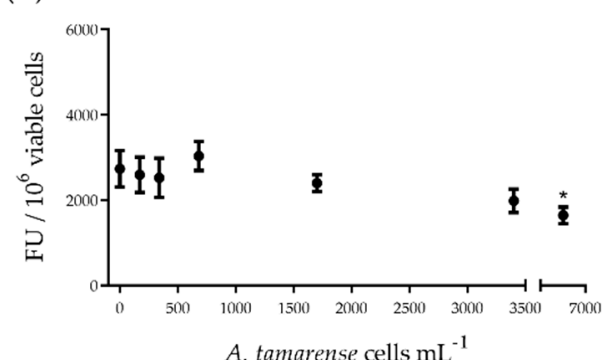

Figure 3. (a,b) Extracellular $\mathrm{H}_{2} \mathrm{O}_{2}$ and (c,d) intracellular ROS levels in Mytilus edulis hemocytes exposed in vitro to PSTs or to extracellular LCs from Alexandrium strains (Alex5 and Alex NX-57-08, respectively). PST and LC concentrations are expressed as the equivalent number of Alexandrium spp. cells $\mathrm{mL}^{-1}$. Results are presented as mean \pm SEM. Asterisks denote significant differences between an individual treatment and the control $\left({ }^{*} p<0.05 ;{ }^{* *} p<0.01\right.$; $\left.{ }^{* *} p<0.001\right), n=5$ mussels per treatment.

Mitochondrial membrane potential (MMP) was examined only in hemocytes attached to the coverslip that show no conspicuous change in morphology, following $4 \mathrm{~h}$ of incubation. MMP in hemocytes was neither affected by PST $(1250 \mu \mathrm{M}$, corresponding to 6900 A. catenella cells $\mathrm{mL}^{-1}$ ) nor LC (supernatant from 6800 A. tamarense cells $\mathrm{mL}^{-1}$ ) exposure (Figure 4). Immune cell clumping was only seen in the PST treatment.

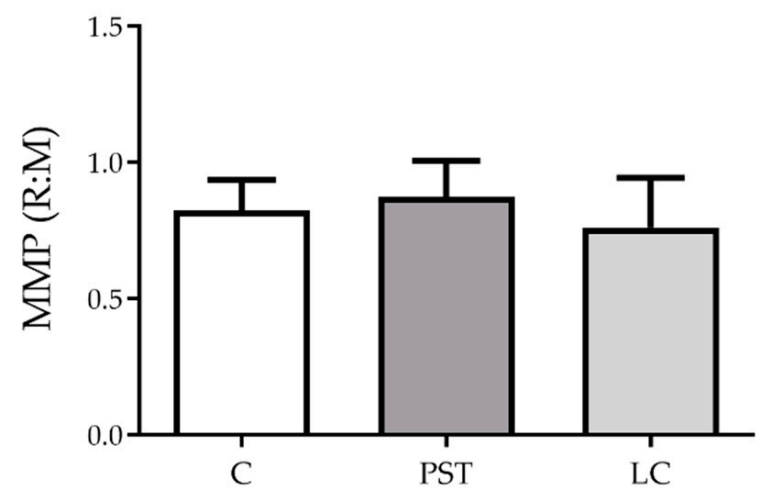

Figure 4. Equivalent to the mitochondrial membrane potential (MMP) given as the ratio of reversible red staining and mononomeric green staining R:M in Mytilus edulis hemocytes exposed in vitro to PSTs and extracellular LCs from Alexandrium strains (Alex5 and Alex NX-57-08, respectively). JC-10 stain of control (C), PST ( $1250 \mu \mathrm{M}$, corresponding to 6900 A. catenella cells $\left.\mathrm{mL}^{-1}\right)$ and LC (supernatant from 6800 A. tamarense cells $\mathrm{mL}^{-1}$ ) treatments. Results are presented as mean $\pm \mathrm{SEM}, n=6$ (mussels per treatment).

Cytotoxic and functional variables tested in hemocytes in the dose-response in vitro approach were correlated with each other and presented as a Pearson correlation matrix (Table 1). For PST exposure, variation in cellular viability showed a strong positive correla- 
tion with lysosomal membrane damage; however, all these variables had no relationship with phagocytic activity. For LC, the lysosomal membrane stability variation showed a significantly positive correlation with cellular viability and phagocytosis. For both bioactive compound classes, there was no relationship between ROS levels and phagocytosis. The correlation between cellular viability and ROS levels is not further discussed since ROS was measured in living cells, so these variables are not actually related.

Table 1. Pearson correlation matrix (coefficient of correlation, $\mathrm{r}^{2}$ ) for cytotoxic and functional variables tested in Mytilus edulis hemocytes exposed in vitro to paralytic shellfish toxins (PSTs) or to extracellular lytic compounds (LCs) from Alexandrium strains (Alex5 and Alex NX-57-08, respectively).

\begin{tabular}{ccccccc}
\hline \multicolumn{1}{c}{ PST } & $\mathbf{1}$ & $\mathbf{2}$ & $\mathbf{3}$ & $\mathbf{4}$ & $\mathbf{5}$ \\
\hline 1 & Cell Viability & 1.00 & & & & \\
2 & LMS & $0.68^{*}$ & 1.00 & & & \\
3 & Phagocytosis & 0.14 & -0.46 & 1.00 & & \\
4 & Intracellular ROS & $0.68^{*}$ & 0.65 & -0.25 & 1.00 & \\
5 & Extracellular $\mathrm{H}_{2} \mathrm{O}_{2}$ & $0.76^{*}$ & $0.91^{* *}$ & -0.30 & $0.82^{*}$ & 1.00 \\
\hline \multicolumn{1}{c}{ LC } & $\mathbf{1}$ & $\mathbf{2}$ & $\mathbf{3}$ & $\mathbf{4}$ & $\mathbf{5}$ \\
\hline 1 & Cell Viability & 1.00 & & & & \\
2 & LMS & $0.71^{*}$ & 1.00 & & & \\
3 & Phagocytosis & 0.69 & $0.98^{* * *}$ & 1.00 & & \\
4 & Intracellular ROS & 0.03 & 0.63 & 0.65 & 1.00 & \\
5 & Extracellular $\mathrm{H}_{2} \mathrm{O}_{2}$ & 0.45 & 0.30 & 0.34 & -0.33 & 1.00 \\
\hline$p<0.05 ; * * p<0.01 ; * * *<0.0001$. LMS: lysosomal membrane stability. & & & &
\end{tabular}

\subsection{Toxin Scavenger Function}

\subsubsection{In Vitro Chemical Effects of PST and LC on $\mathrm{H}_{2} \mathrm{O}_{2}$ Levels}

Both PSTs and LCs dampened $\mathrm{H}_{2} \mathrm{O}_{2}$ concentration in vitro. PSTs significantly reduced $\mathrm{H}_{2} \mathrm{O}_{2}$ levels at all tested concentrations as compared to control (ANOVA $p<0.01$; Dunnett's test $p<0.05$ for 250 and $500 \mu \mathrm{M}$, corresponding to 1380 and 2760 A. catenella cells $\mathrm{mL}^{-1}$; $p<0.01$ for $1250 \mu \mathrm{M}$, corresponding to 6900 cells mL $^{-1}$ ) (Figure 5a). Addition of LCs to the $\mathrm{H}_{2} \mathrm{O}_{2}$ detecting system caused a dose-dependent scavenging effect across all concentrations (linear regression, $\mathrm{r}^{2}=0.77, p<0.001$ ), with a significant effect on the supernatant from 6800 A. tamarense cells $\mathrm{mL}^{-1}$ (ANOVA $p<0.01$; Dunnett's test $p<0.05$ ) (Figure $5 \mathrm{~b}$ ).

(a)

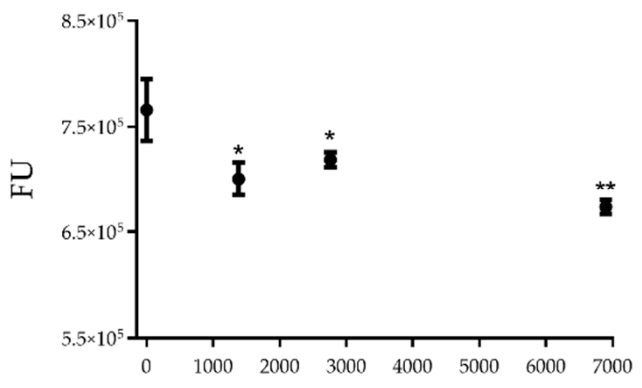

A. catenella cells $\mathrm{mL}^{-1}$ (b) $\quad$ LC

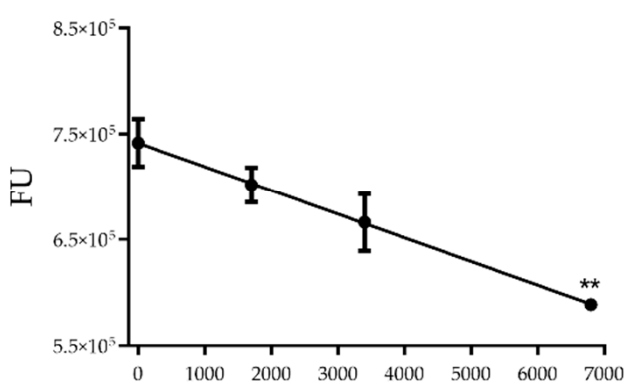

A. tamarense cells $\mathrm{mL}^{-1}$

Figure 5. In vitro scavenger effect of (a) PSTs and (b) LCs from Alexandrium strains (Alex5 and Alex NX-57-08, respectively) on $\mathrm{H}_{2} \mathrm{O}_{2}$. PST and LC concentrations are expressed as the equivalent number of Alexandrium spp. producer cells $\mathrm{mL}^{-1}$. Results are presented as mean \pm SEM. Asterisks denote significant differences between an individual treatment and the control $\left({ }^{*} p<0.05 ;{ }^{* *} p<0.01\right), n=4$ per treatment. 


\section{Discussion}

From our in vitro dose-response studies, we can show and compare the separate actions of different dinoflagellate secondary metabolites on the immune cells of the blue mussel Mytilus edulis. PSTs and LCs from Alexandrium strains (A. catenella strain Alex5 and $A$. tamarense strain Alex NX-57-08, respectively) are bioactive substances that affect the cellular integrity and immune function of hemocytes, acting dose dependently in some cases. However, interpretation of functional and cytotoxic in vitro markers has to be performed with caution when comparing different published results. Generally, it has to be considered that PST extracts and LC containing supernatant are not pure or single compounds. Using dilute acetic acid as an extraction solvent for PSTs, mainly inorganic and polar organic compounds are extracted, and the majority of organic cell contents are excluded, but the presence of other molecules in PST extracts cannot be discarded. Likewise, the culture supernatant may include BECs other than the lytic compounds, and lytic bacteria may also be present, as algal cultures were not axenic. Further systematic testing including additional controls (i.e., the cellular extract of a non-PST strain; supernatant of a non-BEC strain), and/or with pure PSTs (single compounds and mixtures) would complement these assessments.

\subsection{PST vs. LC: In Vitro Cytotoxic and Functional Effects}

The exponential dose-dependent increase in cellular death, observed in our in vitro assay for M. edulis hemocytes exposed to A. catenella (Alex5) PST extract, is likely due to caspase-dependent apoptosis, as has been shown for hemocytes of many bivalve species exposed to STX, gonyautoxins (e.g., GTX2/3), or B1 and C1/C2 [32,33]. Indeed, Abi-Khalil et al. [33] found that a few hours of exposure to elevated concentrations of purified PSTs cause dose-dependent morphological alterations, the permeabilization of cytoplasmic and nuclear membranes, DNA damage, and hemocyte death in oysters. In our study, cellular death is positively correlated with the loss of lysosomal membrane stability in M. edulis hemocytes exposed to PST extract. This subcellular damage could be explained based on previous studies by (i) a release of intracellular lytic enzymes, triggered as part of the detoxification process against PSTs [20], but not directly correlated with phagocytosis in our work; and (ii) by a direct binding of toxin molecules to membrane ion channels affecting the lysosomal membrane functionality [34]. In fact, the regulation of cell membrane permeability, by blocking $\mathrm{Na}^{+}$channels under ionic stress conditions, is one of the biological functions suggested for STX in the producer algae (reviewed by [35]). The cytotoxic effect of LCs is not related to the induction of programmed cell death but to the direct disruption of cytoplasmic membranes causing their permeabilization and altering the cellular homeostatic balance [23]. In our work, the lethal effect on M. edulis hemocytes is restricted and stabilizes as LC concentrations increase. This limited sensitivity of membranes to the lysis could be showing the variable content of targeted constituents such as sterols and phosphatidylcholine [26] expressed in the hemocyte subpopulations [36].

All in all, the cytotoxicity parameters evaluated for PST exposure on M. edulis hemocytes appears to be of limited severity in our study, which could be attributed to known mechanisms of ligand-receptor interaction for toxin elimination [20], cellular ion homeostasis [21], and regeneration capacity [18]. Contrary to PSTs, there is no evidence of LCs entering the cytoplasm of live cells, but the resulting harmful effect at the subcellular level is indeed stronger for LC-containing supernatant than for PST-containing cell extract. This subcellular effect is positively correlated with cellular death and is displayed as an exponential function of the dose-dependent labilization of lysosomal membranes, probably linked to a general homeostatic destabilization in hemocytes such as changes in cytoplasmic $\mathrm{pH}$ and osmolarity [34].

The cellular immune response is distinctly affected by the PST extract and extracellular LCs. Despite increased cellular death and lysosomal destabilization caused by PST exposure in M. edulis hemocytes, there is no correlation between these individual variables and phagocytic activity for yeast cells, which is indeed stimulated at low doses. 
These toxins can be recognized by hemocytes as non-self molecules as they trigger the over-expression of Pattern Recognition Receptor (PRR) genes related to the recognition of glycan and carbohydrates (such as galectins and lectins) in fungi cell walls $[18,21,37]$. An overwhelmed receptor response in M. edulis hemocytes exposed to increased toxin dosage could explain the decrease of phagocytosis to control levels, affected by the PST extract (Figure 2a). ROS production does not correlate with the phagocytic activity induced by PSTs in M. edulis hemocytes. In fact, these toxins do not elicit much intracellular ROS production and diminish the amounts of ROS released into the medium. This was corroborated in our in vitro $\mathrm{H}_{2} \mathrm{O}_{2}$ scavenging test, even at the lowest toxin concentration $(250 \mu \mathrm{M}$, corresponding to $1380 \mathrm{~A}$. catenella cells $\mathrm{mL}^{-1}$ ). PST antioxidant potential could account for a biological function neutralizing excessive ROS production in algae cells such as when these microorganisms are under oxidative stress conditions during a "bloom" [38]. PST effect on hemocyte intracellular ROS production at the highest tested doses seems to be more of an indirect effect and not related to the disruption of the MMP, which is unaffected by the toxin in our in vitro assay. The increased expression of mitochondrial enzymes and voltage-gated channel proteins was observed in M. chilensis following STX exposure, which is suggested as a mechanism for maintaining mitochondrial stability [21]. Contrary to PSTs, subcellular destabilization caused by the exposure to LC containing supernatant is strongly correlated with phagocytic activity, which decreases at a dose-dependent exponential function, probably because osmotic unbalance also impairs invagination and adhesion processes [9]. The LC effect on cellular ROS production is not clear, except at a very high concentration where intracellular ROS levels decrease. This is not accompanied by a change in MMP in M. edulis hemocytes at the same LC concentration. Indeed, the $\mathrm{H}_{2} \mathrm{O}_{2}$ scavenging test revealed a linear relationship between quenching and the applied LC doses, which evidences a direct and clear antioxidant effect of the compounds from the Alexandrium culture supernatant. It has been speculated that extracellular ROS is involved in the toxicity of Alexandrium and other HAB species [39], but this is not necessarily due to a direct effect on target organisms. Instead, synergistic interactions between ROS and PUFA/LC-PUFA released by Alexandrium may lead to the production of toxic secondary metabolites by lipid peroxidation processes [40]. It has been shown that scavenging of extracellular ROS impairs growth population in HAB species [41,42]. Although, the possible allelochemical/physiological role of the antioxidant effect of BECs from A. tamarense (NX-57-08) evidenced in our results has not been elucidated. Increased knowledge of the chemical nature of BECs (lytic and others) is necessary to fully describe this process.

\subsection{In Vitro vs. In Vivo Effects}

Few publications have addressed and compared the in vivo and in vitro effects of bioactive compounds in bivalve model species, which limits our ability to compare the present results and draw definite conclusions toward the biochemical mechanisms underlying their mode of action. In a previous study from this project, mussels were fed the same Alexandrium strains used in the present work, Alex5 (PST) and Alex NX-57-08 (LC), for three and seven days, in order to study the in vivo effects of both compound types and those of their combined application (also using a PST+LC producer strain). PST and LC doses used for in vitro exposure correspond to those produced by Alexandrium spp. at a density that $M$. edulis can easily consume/tolerate during in vivo exposure [31]. Accordingly, these algae densities correspond to environmentally realistic conditions registered for HABs of Alexandrium, which are relevant to their effects on bivalves, e.g., [43,44]. Finally, mussels used for in vitro and in vivo exposure assays were collected in the same season and at the same location, were of the same size, and maintained under the same acclimatization conditions. In what follows, we will mainly compare the results of the in vivo and in vitro approaches in our study, individually for each substance class.

Our results indicate that the in vivo and in vitro effects of PST on M. edulis hemocytes are consistent and follow coherent patterns. Cellular viability is similarly affected when mussels are fed for three and seven days with PST-containing but non-lytic A. catenella 
strain Alex5 (10-20\% loss of viability) cells, as when hemocytes are directly exposed to PST extract over $4 \mathrm{~h}$ (max. 15\% viability loss). Dose-dependent effects on cellular death rates are corroborated in vitro from 31.25 to $1250 \mu \mathrm{M}\left(172-6900\right.$ cells $\left.\mathrm{mL}^{-1}\right)$. In addition, labilization of lysosomal membranes is evident and amounts to $\sim 40 \%$ damaged cells in vivo, and between 30 and $50 \%$ in vitro. Phagocytic activity is stimulated in vivo and in vitro; in both cases, the effect is limited and returns to control level at higher PST concentrations, which, for the in vivo experiment, would emulate the accumulation of ingested toxin after seven days. A strong but transient scavenging effect of PSTs on hemocyte ROS production is observed after three feeding days $(60 \%$ for extracellular $-80 \%$ for intracellular) with return to control levels after seven days. This antioxidant effect of the PST extract is corroborated by in vitro tests, with hemocytes exposed to the highest PST dosage, and additionally confirmed in the direct biochemical assays of the $\mathrm{H}_{2} \mathrm{O}_{2}$ scavenging capacity of the samples. These results suggest that cytotoxic effects and initially diminished ROS levels would not impair immunological competence against non-self particles in M. edulis, as in vivo effects are corroborated by in vitro approaches. There are several studies dealing with the effects of STX in vitro exposure and simulated blooms of A. minimum on hemocyte viability, phagocytic activity, and ROS production in hemocytes of C. gigas [4]. Contrary to our findings, the cited investigations show inconsistent results which are attributed to the lack of homogeneity in bivalve populations and algae culture conditions used in these studies. Moreover, comparing single toxin effects with the exposures to living algae limits the accuracy of emerging conclusions.

Results obtained from in vivo and in vitro exposures to LCs are not as consistent, but the immunotoxic potential of LCs from Alexandrium is clearly evident in M. edulis. Cytotoxicity is similar for both exposure conditions, with hemocyte viability $10-20 \%$ affected in vivo and $10-15 \%$ in vitro. In addition, labilization of lysosomal membranes is observed in mussels fed with lytic A. tamarense strain NX-57-08 for three and seven days, with a strong dose-dependent effect corroborated in in vitro experiments. An impairment of phagocytic activity is only observed when LCs are directly administered to hemocytes in vitro but are absent when mussels are fed with producer algae. Similar to PSTs, LCs diminish intracellular and extracellular $\mathrm{H}_{2} \mathrm{O}_{2}$ levels in vivo only in the first experimental phase after three days of feeding. An antioxidant capacity of LC containing supernatant was corroborated in vitro in hemocytes exposed to the highest concentration and in the $\mathrm{H}_{2} \mathrm{O}_{2}$ scavenging assays. In vitro exposure allows for the direct contact of LCs with the hemocytes, while in vivo feeding exposure to the lytic strain may cause indirect deleterious effects driven by a global physiological stress derived from tissue damage, as previously seen in oysters and scallops [28-30]; these consequences may also include the impairment of hemocyte functions other than immunity (tissue repair, nutrition, biomineralization, etc.), as previously suggested for many bivalve species [4]. The difference between these exposure approaches would explain the inconsistency among cytotoxic and immunotoxic effects observed in M. edulis hemocytes under both exposure conditions. Consequently, these results highlight the difficulty in extrapolating mechanistic conclusions from in vitro and in vivo conditions for the exposure of mussels to LCs. A similar outcome is found when the in vitro exposure of P. philippinarum hemocytes to the Karenia selliformis cell-free culture supernatant caused cell death and the inhibition of ROS production [45], while in vivo exposure to a simulated bloom showed no detectable effect [46].

\section{Conclusions}

Bioactive compounds produced by A. catenella (Alex5) and A. tamarense (Alex NX57-08) affect the integrity and functionality of M. edulis hemocytes exposed in vitro. Both compound classes induced similar levels of cell mortality. However, PSTs at low doses may act as immunostimulants of phagocytic activity despite causing moderate damage to lysosomal membranes; on the other hand, LCs are harmful and immunotoxic, impairing lysosomal stability and phagocytosis in a dose-dependent manner. Both compound classes elicit the suppression of intracellular ROS levels, which is not related to a disturbed 
mitochondrial membrane potential, but rather to an indirect physiological disturbance at high doses. Both PSTs obtained from cellular extracts and supernatant containing LCs have a direct scavenger action on ROS in vitro. However, the biological role of the antioxidant properties of these bioactive compounds has not been fully described thus far.

As discussed above, PST and LC doses used in the present study correspond to environmentally relevant algal densities, which bivalves may be exposed to during a HAB. After a comparative analysis of present and previously published results, we conclude that the extrapolation of in vitro cellular effects and responses to in vivo systems is more straightforward for PSTs than for LCs. These kinds of in vitro/in vivo combined approaches could be useful for the evaluation and validation of biomarker responses in the field, but also for the prediction of potential immunomodulatory effects on bivalves upon exposure to algae bioactive products.

\section{Materials and Methods}

\subsection{Preparation of PST Extracts and Extracellular LCS}

PSTs and LCs were obtained from cultures of Alexandrium strains, previously characterized through morphological and phylogenetical analyses. The clone Alex 5 of Alexandrium catenella (formerly group I of the A.tamarense/fundyense/catenella species complex) isolated from the North Sea coast off Scotland [47] has been shown to produce PSTs but not LCs; however, a strain of $A$. tamarense (NX-57-08, formerly group III of the $A$. tamarense /fundyense / catenella species complex) isolated in 2015 from Trondheimfjord (Norway) (Tillmann, unpublished) produces LCs but not PSTs [31]. Both strains were grown in 250 mL glass Erlenmeyer's flasks, with seawater K-medium supplemented with selenite, prepared from $0.2 \mathrm{~mm}$ sterile-filtered (VacuCap, Pall LifeSciences, Dreieich, Germany) North Sea seawater (salinity 32) at $15^{\circ} \mathrm{C}$, under cool-white fluorescent light at a photon flux density (PFD) of $100 \mu \mathrm{mol}$ photons $\mathrm{m}^{-2} \mathrm{~s}^{-1}$ in a $16 \mathrm{~h}$ light:8 h dark photo-cycle. Cultures were harvested in the early stationary phase.

For PST extraction, cell pellets of $A$. catenella, obtained by centrifugation at $3200 \times g$ for $15 \mathrm{~min}$, were transferred with a $500 \mu \mathrm{L}$ extraction solvent $(0.03 \mathrm{~N}$ acetic acid) into a FastPrep tube containing ca. $0.9 \mathrm{~g}$ lysing matrix D. The tubes were placed in a FastPrep instrument to homogenize the samples at a speed of 6.5 for $45 \mathrm{~s}$. After that, samples were centrifuged for $15 \mathrm{~min}$ at $8100 \times g$ and $4{ }^{\circ} \mathrm{C}$. The supernatant $(400 \mu \mathrm{L})$ was filtered through a pore-sized $0.45 \mu \mathrm{m}$ filter by centrifugation for $30 \mathrm{~s}$ at $800 \times g$. Filtrate was transferred to an HPLC vial. Using acetic acid as an extraction solvent, mainly inorganic and polar organic compounds were extracted, and the majority of organic cell contents were excluded. Toxin profiles and content were analyzed by reverse-phase ion-pair liquid chromatography coupled to postcolumn derivatization and fluorescence detection (LC-FD) based on previously published methods $[48,49]$. Data were calibrated against external PST calibration curves prepared from standards that were purchased from the Certified Reference Material Programme of the Institute of Marine Biosciences, National Research Council, Halifax, NS, Canada. Results are expressed as ng per $\mu \mathrm{L}$ and $\mu \mathrm{M}$ of extract (Table 2). This PST solution was preserved at $-20^{\circ} \mathrm{C}$ for one month, before being used in the in vitro exposures.

Table 2. Stock PST concentrations (ng $\mu \mathrm{L}^{-1}$ and $\mu \mathrm{M}$ ) measured in acetic acid extracts of Alexandrium catenella cells (Alex5 strain) and used for the in vitro exposures of Mytilus edulis hemocytes.

\begin{tabular}{ccc}
\hline PST & ng $\boldsymbol{\mu L} \mathbf{L}^{-\mathbf{1}}$ & $\boldsymbol{\mu M}$ \\
\hline STX & 4.3 & 14 \\
NEO & 63.5 & 200 \\
GTX 1/4 & 105.2 & 255 \\
GTX 2/3 & 0.7 & 2 \\
C1/C2 & 94.3 & 199 \\
Total concentration & 268.1 & 670 \\
\hline
\end{tabular}


For the assessment of the lytic capacity of bioactive compounds from $A$. tamarense (NX-56-08), the original culture containing 13,637 cells $\mathrm{mL}^{-1}$ was centrifuged (15 min at $3200 \times g)$, and the supernatant containing lytic bioactive compounds was slowly pipetted to avoid cell debris resuspension. The lytic capacity of the culture supernatant was quantified by a cryptophyte Rhodomonas salina (strain KAC30) bioassay according to Tillmann et al. [24]. $\mathrm{EC}_{50}$ was calculated by fitting data points (log-transformed A. tamarense cells $\mathrm{mL}^{-1}$, corresponding to the amount of supernatant in the sample, vs. \% of $R$. salina intact cells) to a sigmoidal curve (see Tillmann et al. [25] for the sigmoidal curve equation) by non-linear regression using Statistica. The $\mathrm{EC}_{50}$ for this culture was 556 cells $R$. salina per $\mathrm{mL}$ with a $95 \%$ confidence interval of 518-597 (Figure 6). The supernatant was stored in the dark for one month at $-20{ }^{\circ} \mathrm{C}$ before being used in the in vitro exposures, and such storage conditions have been reported to preserve lytic activity. Since LCs are known to attach to surfaces such as those of microcentrifuge tubes, a partial decrease in the supernatant lytic activity during hemocyte in vitro exposure cannot be discarded (Section 5.4) [27].

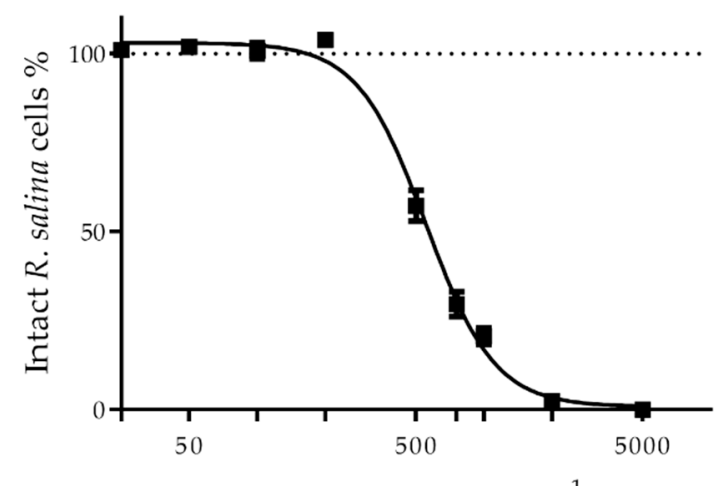

A. tamarense cells $\mathrm{mL}^{-1}$

Figure 6. Rhodomonas salina bioassay showing lytic activity in the culture supernatant of Alexandrium tamarense (AlexNX-56-08), used for the in vitro exposures of Mytilus edulis hemocytes. Results are presented as mean $\pm \mathrm{SD}, n=3$.

\subsection{Mussel Collection and Maintenance}

As previously published [31], adult M. edulis (44.9 $\pm 2.2 \mathrm{~mm}$ of shell length, commercial size) were collected on the island of Sylt and transported to the Alfred Wegener Institute in Bremerhaven. According to official controls, these areas are not affected by toxic blooms. Mechanically cleaned mussels were acclimatized for 21 days in tanks with circulating seawater (salinity $32.8,8.13 \pm 0.5^{\circ} \mathrm{C}, 0.15 \mathrm{mg} \mathrm{L}^{-1} \mathrm{NH}_{4}{ }^{+}, 0.02 \mathrm{mg} \mathrm{L}^{-1} \mathrm{NO}_{2}{ }^{-}$, $26.53 \mathrm{mg} \mathrm{L}^{-1} \mathrm{NO}_{3}{ }^{-}$, $\mathrm{pH} 8.02,10.68 \mathrm{mg} \mathrm{L}^{-1}$ dissolved oxygen). Mussels were fed every seven days with Nannochloropsis salina cells (PhytoMaxx $\mathrm{N}^{\circ} 12009$, Nyos ${ }^{\circledR}$ Aquatics GmbH, Korntal-Münchingen, Germany) at manufacturer's recommended amounts according to mussel number and water tank volume. No mortality was observed under these conditions during the acclimatization period.

\subsection{Hemocyte Extraction and Manipulation}

Mussels were kept on ice for 5 min before hemolymph extraction. Hemolymph was drawn from the posterior adductor muscle of each mussel using a sterile syringe, aliquoted in microcentrifuge tubes, and kept on ice for immediate analysis. The syringe was prefilled with a sterile Alseve medium $\left(20.8 \mathrm{~g} \mathrm{~L}^{-1}\right.$ glucose; $8 \mathrm{~g} \mathrm{~L}^{-1}$ sodium citrate; $3.36 \mathrm{~g} \mathrm{~L}^{-1}$ EDTA; $22.5 \mathrm{~g} \mathrm{~L}^{-1} \mathrm{NaCl}$; pH 7; 920 mOsm; [50]) (1:5, medium:hemolymph) as anticoagulant and a nutritive medium for the cells (except for phagocytic activity assays). Briefly, after extraction and before in vitro exposure, the total number (cells $\mathrm{mL}^{-1}$ ) and viability of hemocytes in each sample was determined microscopically in quadruplicate using a Fuchs Rosenthal chamber (see Section 5.4.2). Cellular density was adjusted using an Alseve medium, when appropriate. 


\subsection{PST and LC Effects on Hemocytes}

\subsubsection{In Vitro Experimental Design}

Hemocyte exposures to PSTs or extracellular LCs were carried out in microcentrifuge tubes kept in the dark, open and cold (over ice, $8-10^{\circ} \mathrm{C}$ ), with orbital shaking (Schüttler KS130 Control, IKA Werke, Staufen, Germany) at $0.05 \times g$, for $4 \mathrm{~h}$. Cellular viability under control in vitro conditions was checked in previous assays using the trypan blue staining method (see Section 5.4.2). Hemocyte viability was stable, at least up to $5 \mathrm{~h}$ $(96.3 \pm 0.6 \%$ at $1 \mathrm{~h} ; 93.0 \pm 1.0 \%$ at $2 \mathrm{~h} ; 94.0 \pm 4.0 \%$ at $3 \mathrm{~h} ; 92.7 \pm 1.2 \%$ at $4 \mathrm{~h} ; 93.7 \pm 2.1 \%$ at $5 \mathrm{~h}$; one-way ANOVA $p=0.31, n=6$ ). Filtered sea water (FSW) used for toxin dilution was prepared in optimal physiological conditions previously measured in hemolymph: 920 mOsm (Vapro Osmometer 5500, Wescor Inc., Logan, UT, USA), salinity 25.4, and pH 7.4 (Microprocessor pH-mV Meter pH526, WTW, Weilheim, Germany). Filtered seawater in these new conditions will be called modified filtered seawater (mFSW) hereafter.

For PST exposure, an aliquot of the cell extract (see Section 5.1) was thawed and the acetic acid extract was dried under a stream of nitrogen. The residue was then combined in $\mathrm{mFSW}$ to reach $62.5,125,250,500,1000$, and $2500 \mu \mathrm{M}$ (working solutions). For extracellular LC exposure, an aliquot of the frozen supernatant was thawed, vigorously shaken, and diluted with deionized water $(0.28 \mathrm{~mL}$ per $\mathrm{mL}$ of supernatant) to reduce salinity to 25.4 . Working solutions were prepared by diluting this preparation with mFSW at 2.5, 5, 10, 25, $50,100 \%$. Both PST and LC working solutions were kept on ice and immediately used. Final concentrations were obtained from the in vitro assays by a 1:2 dilution (PST: 31.25, 62.5, $125,250,500,1250 \mu \mathrm{M} ; \mathrm{LC}: 1.25,2.5,5,12.5,25,50 \%)$. Both PST and LC doses were chosen within the range of toxin concentrations that $M$. edulis could easily consume/tolerate during in vivo exposure [31]. Particularly for LCs, the concentration range corresponds to the densities of A. tamarense cells used in the R. salina assay (Section 5.1). For a comparative analysis of their physiological effects on hemocytes, PST/LC concentrations are expressed from now on as the number of producer Alexandrium cells $\mathrm{mL}^{-1}$ determined in the original culture and corresponding to the working concentrations used for the in vitro exposures. Doses and corresponding cell densities are listed in Table 3, from cultures of 4734 cell

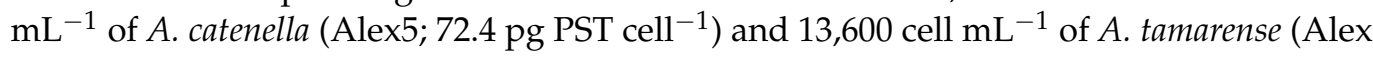
NX-57-08).

Table 3. Estimated number of Alexandrium spp. cells $\mathrm{mL}^{-1}$ (Alex5 and Alex NX-57-08) corresponding to PST $(\mu \mathrm{M})$ and LC (\% of culture supernatant) concentrations used for the in vitro exposures of Mytilus edulis hemocytes.

\begin{tabular}{|c|c|c|}
\hline & $\mu \mathrm{M} / \%$ & Cells $\mathrm{mL}^{-1}$ \\
\hline \multirow{6}{*}{ PST } & 1250 & 6900 \\
\hline & 500 & 2760 \\
\hline & 250 & 1380 \\
\hline & 125 & 690 \\
\hline & 62.50 & 345 \\
\hline & 31.25 & 172.5 \\
\hline \multirow{6}{*}{ LC } & 50 & 6800 \\
\hline & 25 & 3400 \\
\hline & 12.5 & 1700 \\
\hline & 5 & 680 \\
\hline & 2.5 & 340 \\
\hline & 1.25 & 170 \\
\hline
\end{tabular}

Hemocyte in vitro exposures were carried out separately for each toxin and for each cellular variable following a repeated measures design, where each mussel hemocyte sample was aliquoted and exposed to PST or LC serial dilutions. Control treatments with mFSW were set for each sample and measurement. 


\subsubsection{Cytotoxicity}

Lysosomal membrane stability was assessed using the Neutral Red Retention (NRR) assay adapted for microplate reading by Coles et al. [51] and modified in Bianchi et al. [31]. For each toxin concentration, $300 \mu \mathrm{L}$ hemolymph $\left(233,500 \pm 42,650\right.$ cells $\left.\mathrm{mL}^{-1}\right)$ was mixed with $300 \mu \mathrm{L}$ of the corresponding PST or LC treatment and incubated as described in Section 5.4.1. ( $n=4$ by duplicate, each $n$ is a hemolymph sample, pooled from two animals). A total of $300 \mu \mathrm{L}$ of the $200 \mu \mathrm{M}$ neutral red solution was subsequently added to the samples, incubated for $1 \mathrm{~h}$ and centrifuged $\left(800 \times g, 5 \mathrm{~min}\right.$ at $\left.10^{\circ} \mathrm{C}\right)$. A neutral red stain was extracted from the cell pellet with a lysis buffer ( $1 \%$ acetic acid and $50 \%$ ethanol in distilled water) and centrifuged again. Absorbance of the supernatant was read at $550 \mathrm{~nm}$ in a 96-well plate using a microplate reader (TRISTAR, Fa. Berthold, Bad Wildbad, Germany). Results are expressed as optical density (OD) per $\mu \mathrm{g}$ of protein, determined by the Bradford method [52], with less absorbance indicating stronger labilization of lysosomal membranes.

Hemocyte viability was measured using the trypan blue staining method (modified from Akaishi et al. [53]). In total, $100 \mu \mathrm{L}$ of hemolymph was centrifuged $(500 \times g$, for $20 \mathrm{~min}$ at $4{ }^{\circ} \mathrm{C}$ ) to eliminate the humoral compartment, and cells were re-suspended in the same volume of the Alseve medium (Section 5.3). Cell suspension (207,200 $\pm 30,695$ cells $\mathrm{mL}^{-1}$ ) was mixed with $100 \mu \mathrm{L}$ of the corresponding PST or LC treatment and incubated (Section 5.4.1). In total, $50 \mu \mathrm{L}$ of trypan blue stain $0.2 \%$ in PBS (Sigma-Aldrich, Steinheim, Germany) was added and samples were incubated at $4{ }^{\circ} \mathrm{C}$ for $5 \mathrm{~min}$. Live (unstained) and dead cells (stained) were counted within 15 min, using a Fuchs Rosenthal chamber and a light microscope. The number of viable hemocytes $\mathrm{mL}^{-1}$ is expressed as percentage of total cells $(n=5$, each one is an individual mussel).

\subsubsection{Cellular Function}

Phagocytic activity was assessed using yeast cells stained with Congo red (SigmaAldrich, Saint Louis, MO, USA) based on the protocols of Kuchel et al. [54] and detailed in Bianchi et al. [31]. Fifty microliters of hemolymph $\left(207,100 \pm 23,057\right.$ cells $\left.\mathrm{mL}^{-1}\right)$ was mixed with $50 \mu \mathrm{L}$ of the corresponding PST or LC treatment and incubated (Section 5.4.1). Subsequently, a stained yeast suspension containing twice the amount of yeast cells over the number of viable hemocytes was added to each sample and incubated for $30 \mathrm{~min}$ on ice. After the incubation, cells were preserved with $1 \%$ glutaraldehyde at $4{ }^{\circ} \mathrm{C}$. Phagocytic activity was calculated by dividing the total number of phagocytosed yeast cells in 100 hemocytes, which were analyzed per sample under the light microscope. Results are expressed as the number of phagocytosed yeast cells per hemocyte $(n=5$, each one is an individual mussel).

Reactive oxygen species (ROS) production was evaluated in cell suspensions for both intracellular ROS and extracellular $\mathrm{H}_{2} \mathrm{O}_{2}$. After centrifugation of hemolymph $(500 \times g$, $20 \mathrm{~min}$ at $\left.4{ }^{\circ} \mathrm{C}\right)$, the supernatant was removed, and cells were re-suspended in the Alseve medium (Section 5.3) and kept on ice for $30 \mathrm{~min}$. Hemocyte viability was evaluated by the trypan blue stain method (Section 5.4.2) before analysis. Intracellular ROS production was measured using the ROS reactive fluorescent probe dichlorofluorescein-diacetate $\left(\mathrm{H}_{2} \mathrm{DCF}\right.$ DA, Invitrogen, Carlsbad, CA, USA) based on the protocol of Moss and Allam [55], with detailed modifications according to Bianchi et al. [31]. Triplicate aliquots of $100 \mu \mathrm{L}$ containing 50,000 viable cells from each mussel ( $n=5$, each one is an individual mussel) were mixed with $100 \mu \mathrm{L}$ of the corresponding PST or LC treatment and incubated (Section 5.4.1). After incubation, $40 \mu \mathrm{L}$ of the supernatant was slowly drawn with a pipette and a final concentration of $40 \mu \mathrm{M}$ of $\mathrm{H}_{2}$ DCF-DA was added (200 $\mu \mathrm{L}$ final volume). Changes in fluorescence units were red at excitation/emission: $485 / 530 \mathrm{~nm}$ for $1 \mathrm{~h}$, using a microplate reader (TRISTAR, Berthold, Bad Wildbad, Germany). Results are expressed as fluorescent units (FU) per $10^{6}$ viable cells. Based on manufacturer's protocol, extracellular $\mathrm{H}_{2} \mathrm{O}_{2}$ levels were measured using Amplex ${ }^{\circledR}$ UltraRed reagent (AmR, life technologies, Carlsbad, CA, USA), a fluorogenic substrate for horseradish peroxidase (HRP, GE Healthcare, Chicago, $\mathrm{IL}$, USA) that reacts with the hydrogen peroxide $\left(\mathrm{H}_{2} \mathrm{O}_{2}\right)$ produced and released by cells. 
Triplicate aliquots of $100 \mu \mathrm{L}$ containing 50,000 viable cells from each mussel $(n=5$, each one is an individual mussel) was mixed with $100 \mu \mathrm{L}$ of the corresponding PST or LC treatment and incubated (Section 5.4.1). After incubation, $40 \mu \mathrm{L}$ of the supernatant was slowly drawn with a pipette and a final concentration of $50 \mu \mathrm{M}$ of fluorescent probe and $0.2 \mathrm{U} \mathrm{mL}^{-1}$ of enzyme were added ( $200 \mu \mathrm{L}$ final volume). Changes in fluorescence units were followed for $1 \mathrm{~h}$ at excitation/emission: 550/590 nm, using a microplate reader (TRISTAR, Berthold). Results are expressed as FU per $10^{6}$ viable cells.

Changes in mitochondrial membrane potential (MMP) were evaluated using the JC10 fluorescent stain (Enzo Life Sciences ENZ-52305, Doral, FL, USA). Forty microliters of hemolymph $\left(181,500 \pm 37,034\right.$ cells $\left.\mathrm{mL}^{-1}\right)$ was placed on poly-L-lysine coated slides (NeuvitroGG-12-PLL, Vancouver, WA, USA) and incubated for $20 \mathrm{~min}$ in a wet chamber to let cells attach to the coverslip. Then, $20 \mu \mathrm{L}$ of supernatant was slowly drawn with a pipette and $20 \mu \mathrm{L}$ of the corresponding PST or LC treatment was added. Samples were subsequently incubated for $4 \mathrm{~h}$ in the dark. Only the highest doses previously tested for each toxin were applied in this assay (PST: $1250 \mu \mathrm{M}$, corresponding to $6900 \mathrm{~A}$. catenella cells $\mathrm{mL}^{-1}$; LC: culture supernatant from $6800 \mathrm{~A}$. tamarense cells $\mathrm{mL}^{-1}$ ). After incubation, the supernatant was gently removed and $40 \mu \mathrm{L}$ of the JC-10 solution $(10 \mu \mathrm{M}$, from $1 \mathrm{mM}$ stock in DMSO) was added and allowed to react for $1 \mathrm{~h}$. Fluorescence intensity was measured in 20 adherent cells of each treatment $(n=6$, each one corresponding to the mean of 20 cells per individual mussel) using a confocal microscope (SP5, Leica, Wetzlar, Germany). Images were analyzed using the software Leica advanced fluorescence lite, and differences in MMP were calculated as the ratio between reversible red fluorescent JC-10 aggregates (excitation/emission: 540/590 nm) and its monomeric, green fluorescent form (excitation/emission: 490/525 nm), and expressed as Reversible:Monomeric (R:M). Autofluorescence in each sample was measured as the control baseline by adding the corresponding DMSO solution in buffer without JC-10.

\subsection{Scavenger Effects in PST and LC Treatments}

5.5.1. In Vitro Chemical Effects of PST and LC Treatments on $\mathrm{H}_{2} \mathrm{O}_{2}$ Levels

Amplex ${ }^{\circledR}$ UltraRed reagent (AmR, life technologies, Carlsbad, CA, USA) is oxidized by $\mathrm{H}_{2} \mathrm{O}_{2}$ in the presence of horseradish peroxidase (HRP, GE Healthcare, Chicago, IL, USA) to produce the red fluorescent compound resorufin (max. 563ex/587em nm). The change of emitted fluorescence intensity is directly proportional to the concentration of $\mathrm{H}_{2} \mathrm{O}_{2}$ in the medium. In preliminary testing, suitable $\mathrm{H}_{2} \mathrm{O}_{2}$ substrate concentrations for this assay were evaluated in a range from 0 to $2 \mu \mathrm{M}\left(10 \mu \mathrm{M}\right.$ in deionized water, working solution). $\mathrm{H}_{2} \mathrm{O}_{2}$ was pipetted into a 96-well plate and incubated at room temperature for 2 min with PST $1250 \mu \mathrm{M}$ (from 6800 A. catenella cells $\mathrm{mL}^{-1}$ ) or LC from the 6900 A. tamarense cell $\mathrm{mL}^{-1}$ culture supernatant $(160 \mu \mathrm{L}$ final volume). Then, final concentrations of $50 \mu \mathrm{M}$ of fluorescent probe and $0.2 \mathrm{U} \mathrm{mL}^{-1}$ of enzyme were added ( $200 \mu \mathrm{L}$ final volume). The reagent mix was allowed to react for $5 \mathrm{~min}$ in the dark, and final fluorescence was read at excitation/emission: 550/590 nm using a microplate reader (TRISTAR, Berthold, Bad Wildbad, Germany). Data are presented as FU (mean \pm standard error of mean) vs. $\mathrm{H}_{2} \mathrm{O}_{2}$ concentrations. Results show a linear scavenging response from both PST and LC (linear regression: Control $\mathrm{r}^{2}=0.95 ; \mathrm{LC}^{2}=0.83$; PST $\mathrm{r}^{2}=0.92 ; p<0.0001$ for all) and a significant effect (two-way ANOVA, $p<0.0001$ for individual effects of algal product and peroxide concentration) on $\mathrm{H}_{2} \mathrm{O}_{2}$ concentrations when used as a substrate at $0.5-1.5 \mu \mathrm{M}(n=4)$ (Figure 7).

Based on these data, $1.5 \mu \mathrm{M} \mathrm{H}_{2} \mathrm{O}_{2}$ was chosen as the most sensible concentration to test in vitro scavenging effects of both compound classes. For this, different concentrations of PSTs $\left(250,500\right.$, and $1250 \mu \mathrm{M}$, corresponding to $1380,2760,6900$ A. catenella cells $\left.\mathrm{mL}^{-1}\right)$ and LCs (culture supernatant from 1700, 3400, and 6800 A. tamarense cells $\mathrm{mL}^{-1}$ ) were pipetted in triplicate assays and mixed with $\mathrm{H}_{2} \mathrm{O}_{2}$ into a 96-well plate at a final volume of $160 \mu \mathrm{L}$. After 2 min of incubation, AmR and HRP were added and allowed to react for $5 \mathrm{~min}$, as described above. Final fluorescence was read at excitation/emission: 550/590 nm. 
Results are presented as FU (mean \pm standard error of the mean) vs. toxin concentrations $(n=4)$.

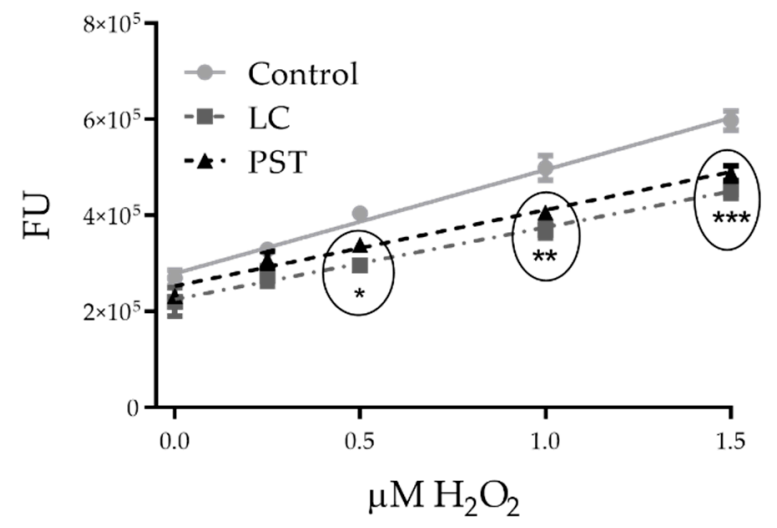

Figure 7. Preliminary testing of $\mathrm{H}_{2} \mathrm{O}_{2}$ concentrations as substrate for Amplex ${ }^{\circledR}$ UltraRed in a toxin scavenging capacity assay (PST: $1250 \mu \mathrm{M}$, corresponding to 6900 Alexandrium catenella cells $\mathrm{mL}^{-1}$; LC: culture supernatant from 6800 Alexandrium tamarense cells $\mathrm{mL}^{-1}$ ). Results are presented as mean \pm SEM. Asterisks denote significant differences among treatments for a given concentration $\left.{ }^{*} p<0.05 ;{ }^{* *} p<0.01 ;{ }^{* *} p<0.001\right), n=4$ per treatment.

\subsection{Statistical Analysis}

Data are presented as mean \pm standard error of mean (SEM). Graph Pad Prism 8 (GraphPad Software, Inc., San Diego, CA, USA) and Statistica 7 (StatSoft, Tulsa, OK, USA) were used for data analysis. Normal distribution and homogeneity of variance were checked with the Kolmogorov-Smirnov and Levene's tests, respectively. Data were transformed to arcsine of the square root when values were expressed as proportions.

Differences among treatments for cytotoxicity and functional variables were assessed using one-way ANOVA of repeated measures and Dunnett's post hoc comparisons to compare treatments against the control. The dose-response effects between PST/LC concentrations and physiological variables were estimated to fit the appropriate regression models. According to Ritz [56], the exponential model was chosen to describe the toxic and functional effects on hemocytes, since this is the nonlinear model recommended to fit decreasing dose-response patterns that only exhibit asymptotic behavior as the dose $(x)$ range is extensive. Doses were not log-transformed to allow for a more accurate graphical representation of the applied functions. Statistical analyses were applied to the raw data, and an effective concentration $50 \%\left(\mathrm{EC}_{50}\right)$ was estimated from this approach. Statistical significance is shown as the standard error of the regression (S). Linear regression was applied to test the scavenging effect of bioactive compounds on ROS (Sections 2.2.1 and 5.5.1), and statistical significance is shown as the coefficient of determination $\left(\mathrm{r}^{2}\right)$. Two-way ANOVA and Tukey's post hoc comparisons were used to test differences among groups in the chemical scavenging test, while a one-way ANOVA of repeated measures and Dunnett's post hoc comparisons were used for the toxin scavenging test on cellular ROS production. One-way ANOVA and Tukey's post hoc comparisons were applied to assess the toxin effect on MMP. In all cases, differences were considered significant at $p<0.05$.

The nested two-tailed multiple correlation test was used to assess the relationship among all variables measured in hemocytes for each bioactive compound. Statistical significance was determined by the Pearson correlation coefficient $\left(\mathrm{r}^{2}\right)$ and $p$ value $<0.05$. 
Author Contributions: Conceptualization, V.A.B., U.B. and D.A.; methodology, V.A.B., U.B., U.T., B.K. and A.M.; validation, V.A.B., U.B., U.T., B.K. and A.M.; formal analysis, V.A.B., U.B., U.T., B.K. and A.M.; investigation, V.A.B., U.T. and A.M.; resources, U.T., B.K. and D.A.; writing—original draft preparation, V.A.B.; writing-review and editing, V.A.B., U.B., U.T., B.K. and D.A.; visualization, V.A.B.; supervision, U.B., U.T., B.K. and D.A.; project administration, D.A.; funding acquisition, V.A.B. and D.A. All authors have read and agreed to the published version of the manuscript.

Funding: This research was funded by a short-term grant from German Academic Exchange Service (DAAD) to VB, $\mathrm{N}^{\circ} 91612818$.

Institutional Review Board Statement: Not applicable.

Informed Consent Statement: Not applicable.

Data Availability Statement: The data presented in this study are openly available on Zenodo (https: / / zenodo.org/, accessed on 7 June 2021) at doi:10.5281/zenodo.4906093.

Acknowledgments: The authors would like to thank Stefanie Meyer for technical support and Lucila Herbert for the art work advice.

Conflicts of Interest: The authors declare no conflict of interest. The funders had no role in the design of the study; in the collection, analyses, or interpretation of data; in the writing of the manuscript, or in the decision to publish the results.

\section{References}

1. Bricelj, V.M.; Shumway, S.E. Paralytic shellfish toxins in bivalve molluscs: Occurrence, transfer kinetics, and biotransformation. Rev. Fish. Sci. 1998, 6, 315-383. [CrossRef]

2. Álvarez, G.; Díaz, P.A.; Godoy, M.; Araya, M.; Ganuza, I.; Pino, R.; Álvarez, F.; Rengel, J.; Hernández, C.; Uribe, E.; et al. Paralytic shellfish toxins in surf clams Mesodesma donacium during a large bloom of Alexandrium catenella dinoflagellates associated to an intense shellfish mass mortality. Toxins 2019, 11, 188. [CrossRef] [PubMed]

3. Landsberg, J.H. The effects of harmful algal blooms on aquatic organisms. Rev. Fish. Sci. 2010, 37-41. [CrossRef]

4. Lassudrie, M.; Hégaret, H.; Wikfors, G.H.; da Silva, P.M. Effects of marine harmful algal blooms on bivalve cellular immunity and infectious diseases: A review. Dev. Comp. Immunol. 2020, 108, 103660. [CrossRef] [PubMed]

5. Schantz, E.J.; Mold, J.D.; Stanger, W.D.; Shavel, J.; Riel, F.J.; Bowden, J.P.; Lynch, J.M.; Wyler, R.S.; Riegel, B.; Sommer, H. Paralytic shellfish poison. VI. A Procedure for the isolation and purification of the poison from toxic clam and mussel tissues. J. Am. Chem. Soc. 1957, 79, 5230-5235. [CrossRef]

6. Vale, P. New saxitoxin analogues in the marine environment: Developments in toxin chemistry, detection and biotransformation during the 2000s. Phytochem. Rev. 2010, 9, 525-535. [CrossRef]

7. Arias, H.R. Marine toxins targeting ion channels. Mar. Drugs 2006, 4, 31-69. [CrossRef]

8. Wiese, M.; D’Agostino, P.M.; Mihali, T.K.; Moffitt, M.C.; Neilan, B.A. Neurotoxic alkaloids: Saxitoxin and its analogs. Mar. Drugs 2010, 8, 2185-2211. [CrossRef]

9. Ford, S.E.; Bricelj, V.M.; Lambert, C.; Paillard, C. Deleterious effects of a nonPST bioactive compound(s) from Alexandrium tamarense on bivalve hemocytes. Mar. Biol. 2008, 154, 241-253. [CrossRef]

10. Fast, M.D.; Cembella, A.D.; Ross, N.W. In Vitro transformation of paralytic shellfish toxins in the clams Mya arenaria and Protothaca staminea. Harmful Algae 2006, 5, 79-90. [CrossRef]

11. Fernández-Reiriz, M.J.; Navarro, J.M.; Contreras, A.M.; Labarta, U. Trophic interactions between the toxic dinoflagellate Alexandrium catenella and Mytilus chilensis: Feeding and digestive behaviour to long-term exposure. Aquat. Toxicol. 2008, 87, 245-251. [CrossRef] [PubMed]

12. Donaghy, L.; Lambert, C.; Choi, K.-S.; Soudant, P. Hemocytes of the carpet shell clam (Ruditapes decussatus) and the Manila clam (Ruditapes philippinarum): Current knowledge and future prospects. Aquaculture 2009, 297, 10-24. [CrossRef]

13. Kádár, E. Haemocyte response associated with induction of shell regeneration in the deep-sea vent mussel Bathymodiolus azoricus (Bivalvia: Mytilidae). J. Exp. Mar. Biol. Ecol. 2008, 362, 71-78. [CrossRef]

14. Hégaret, H.; Wikfors, G.H.; Soudant, P.; Lambert, C.; Shumway, S.E.; Bérard, J.B.; Lassus, P. Toxic dinoflagellates (Alexandrium fundyense and A. catenella) have minimal apparent effects on oyster hemocytes. Mar. Biol. 2007, 152, 441-447. [CrossRef]

15. Bricelj, V.M.; Ford, S.E.; Lambert, C.; Barbou, A.; Paillard, C. Effects of toxic Alexandrium tamarense on behavior, hemocyte responses and development of brown ring disease in Manila clams. Mar. Ecol. Prog. Ser. 2011, 430, 35-48. [CrossRef]

16. Mello, D.F.; da Silva, P.M.; Barracco, M.A.; Soudant, P.; Hégaret, H. Effects of the dinoflagellate Alexandrium minutum and its toxin (saxitoxin) on the functional activity and gene expression of Crassostrea gigas hemocytes. Harmful Algae 2013, 26, 45-51. [CrossRef]

17. Haberkorn, H.; Lambert, C.; Le Goïc, N.; Moal, J.; Suquet, M.; Guéguen, M.; Sunila, I.; Soudant, P. Effects of Alexandrium minutum exposure on nutrition-related processes and reproductive output in oysters Crassostrea gigas. Harmful Algae 2010, 9, 427-439. [CrossRef] 
18. Núñez-Acuña, G.; Aballay, A.E.; Hégaret, H.; Astuya, A.P.; Gallardo-Escárate, C. Transcriptional responses of Mytilus chilensis exposed in vivo to saxitoxin (STX). J. Molluscan Stud. 2013, 79, 323-331. [CrossRef]

19. Wootton, E.C.; Dyrynda, E.A.; Ratcliffe, N.A. Bivalve immunity: Comparisons between the marine mussel (Mytilus edulis), the edible cockle (Cerastoderma edule) and the razor-shell (Ensis siliqua). Fish Shellfish Immunol. 2003, 15, 195-210. [CrossRef]

20. Galimany, E.; Sunila, I.; Hégaret, H.; Ramón, M.; Wikfors, G.H. Experimental exposure of the blue mussel (Mytilus edulis, L.) to the toxic dinoflagellate Alexandrium fundyense: Histopathology, immune responses, and recovery. Harmful Algae 2008, 7, 702-711. [CrossRef]

21. Astuya, A.; Carrera, C.; Ulloa, V.; Aballay, A.; Núñez-Acuña, G.; Hégaret, H.; Gallardo-Escárate, C. Saxitoxin modulates immunological parameters and gene transcription in Mytilus chilensis hemocytes. Int. J. Mol. Sci. 2015, 16, 15235-15250. [CrossRef]

22. Tillmann, U.; John, U. Toxic effects of Alexandrium spp. on heterotrophic dinoflagellates: An allelochemical defence mechanism independent of PSP-toxin content. Mar. Ecol. Prog. Ser. 2002, 230, 47-58. [CrossRef]

23. Ma, H.; Krock, B.; Tillmann, U.; Bickmeyer, U.; Graeve, M.; Cembella, A. Mode of action of membrane-disruptive lytic compounds from the marine dinoflagellate Alexandrium tamarense. Toxicon 2011, 58, 247-258. [CrossRef] [PubMed]

24. Arzul, G.; Seguel, M.; Guzman, L.; Erard-Le Denn, E. Comparison of allelopathic properties in three toxic Alexandrium species. J. Exp. Mar. Biol. Ecol. 1999, 232, 285-295. [CrossRef]

25. Tillmann, U.; Hansen, P.J. Allelopathic effects of Alexandrium tamarense on other algae: Evidence from mixed growth experiments. Aquat. Microb. Ecol. 2009, 57, 101-112. [CrossRef]

26. Ma, H.; Krock, B.; Tillmann, U.; Muck, A.; Wielsch, N.; Svatoš, A.; Cembella, A. Isolation of activity and partial characterization of large non-proteinaceous lytic allelochemicals produced by the marine dinoflagellate Alexandrium tamarense. Harmful Algae 2011, 11, 65-72. [CrossRef]

27. Ma, H.; Krock, B.; Tillmann, U.; Cembella, A. Preliminary characterization of extracellular allelochemicals of the toxic marine dinoflagellate Alexandrium tamarense using a Rhodomonas salina bioassay. Mar. Drugs 2009, 7, 497-522. [CrossRef]

28. Haberkorn, H.; Lambert, C.; Le Goic, N.; Guéguen, M.; Moal, J.; Palacios, E.; Lassus, P.; Soudant, P. Effects of Alexandrium minutum exposure upon physiological and hematological variables of diploid and triploid oysters, Crassostrea gigas. Aquat. Toxicol. 2010, 97, 96-108. [CrossRef] [PubMed]

29. Castrec, J.; Soudant, P.; Payton, L.; Tran, D.; Miner, P.; Lambert, C.; Le Goïc, N.; Huvet, A.; Quillien, V.; Boullot, F.; et al. Bioactive extracellular compounds produced by the dinoflagellate Alexandrium minutum are highly detrimental for oysters. Aquat. Toxicol. 2018, 199, 188-198. [CrossRef] [PubMed]

30. Borcier, E.; Morvezen, R.; Boudry, P.; Miner, P.; Charrier, G.; Laroche, J.; Hegaret, H. Effects of bioactive extracellular compounds and paralytic shellfish toxins produced by Alexandrium minutum on growth and behaviour of juvenile great scallops Pecten maximus. Aquat. Toxicol. 2017, 184, 142-154. [CrossRef]

31. Bianchi, V.; Langeloh, H.; Tillmann, U.; Krock, B.; Müller, A.; Bickmeyer, U.; Abele, D. Separate and combined effects of neurotoxic and lytic compounds of Alexandrium strains on Mytilus edulis feeding activity and hemocyte function. Fish Shellfish Immunol. 2019, 84, 414-422. [CrossRef] [PubMed]

32. Estrada, N.; Ascencio, F.; Shoshani, L.; Contreras, R.G. Apoptosis of hemocytes from lions-paw scallop Nodipecten subnodosus induced with paralyzing shellfish poison from Gymnodinium catenatum. Immunobiology 2014, 219, 964-974. [CrossRef] [PubMed]

33. Abi-Khalil, C.; Finkelstein, D.S.; Conejero, G.; Du Bois, J.; Destoumieux-Garzon, D.; Rolland, J.L. The paralytic shellfish toxin, saxitoxin, enters the cytoplasm and induces apoptosis of oyster immune cells through a caspase-dependent pathway. Aquat. Toxicol. 2017, 190, 133-141. [CrossRef] [PubMed]

34. Xu, H.; Ren, D. Lysosomal physiology. Physiol. Behav. 2017, 176, 139-148. [CrossRef] [PubMed]

35. Brentano, D.M.; Giehl, E.L.H.; Petrucio, M.M. Abiotic variables affect STX concentration in a meso-oligotrophic subtropical coastal lake dominated by Cylindrospermopsis raciborskii (Cyanophyceae). Harmful Algae 2016, 56, 22-28. [CrossRef] [PubMed]

36. Le Grand, F.; Kraffe, E.; Marty, Y.; Donaghy, L.; Soudant, P. Membrane phospholipid composition of hemocytes in the Pacific oyster Crassostrea gigas and the Manila clam Ruditapes philippinarum. Comp. Biochem. Physiol. Part A Mol. Integr. Physiol. 2011, 159, 383-391. [CrossRef] [PubMed]

37. Detree, C.; Núñez-Acuña, G.; Roberts, S.; Gallardo-Escárate, C. Uncovering the complex transcriptome response of Mytilus chilensis against saxitoxin: Implications of harmful algal blooms on mussel populations. PLoS ONE 2016, 11, e0165231. [CrossRef]

38. Zhuang, Y.; Zhang, H.; Hannick, L.; Lin, S. Metatranscriptome profiling reveals versatile N-nutrient utilization, $\mathrm{CO}_{2}$ limitation, oxidative stress, and active toxin production in an Alexandrium fundyense bloom. Harmful Algae 2015, 42, 60-70. [CrossRef]

39. Flores, H.S.; Wikfors, G.H.; Dam, H.G. Reactive oxygen species are linked to the toxicity of the dinoflagellate Alexandrium spp. to protists. Aquat. Microb. Ecol. 2012, 66, 199-209. [CrossRef]

40. Mardones, J.I.; Dorantes-Aranda, J.J.; Nichols, P.D.; Hallegraeff, G.M. Fish gill damage by the dinoflagellate Alexandrium catenella from Chilean fjords: Synergistic action of ROS and PUFA. Harmful Algae 2015, 49, 40-49. [CrossRef]

41. Diaz, J.M.; Plummer, S. Production of extracellular reactive oxygen species by phytoplankton: Past and future directions. J. Plankton Res. 2018, 40, 655-666. [CrossRef] [PubMed]

42. Oda, T.; Moritomi, J.; Kawano, I.; Hamaguchi, S.; Muramatsu, T.; Ishimatsu, A. Catalase- and Superoxide Dismutase-induced morphological changes and growth inhibition in the red tide phytoplankton Chattonella marina. Biosci. Biotechnol. Biochem. 1995, 59, 2044-2048. [CrossRef] 
43. Hégaret, H.; Brokordt, K.B.; Gaymer, C.F.; Lohrmann, K.B.; García, C.; Varela, D. Effects of the toxic dinoflagellate Alexandrium catenella on histopathogical and escape responses of the Northern scallop Argopecten purpuratus. Harmful Algae 2012, $18,74-83$. [CrossRef]

44. Basti, L.; Nagai, S.; Go, J.; Okano, S.; Nagai, K.; Watanabe, R.; Suzuki, T.; Tanaka, Y. Differential inimical effects of Alexandrium spp. and Karenia spp. on cleavage, hatching, and two larval stages of Japanese pearl oyster Pinctada fucata martensii. Harmful Algae 2015, 43, 1-12. [CrossRef]

45. Hégaret, H.; Da Silva, P.M.; Wikfors, G.H.; Haberkorn, H.; Shumway, S.E.; Soudant, P. In Vitro interactions between several species of harmful algae and haemocytes of bivalve molluscs. Cell Biol. Toxicol. 2011, 27, 249-266. [CrossRef] [PubMed]

46. da Silva, P.M.; Hégaret, H.; Lambert, C.; Wikfors, G.H.; Le Goïc, N.; Shumway, S.E.; Soudant, P. Immunological responses of the Manila clam (Ruditapes philippinarum) with varying parasite (Perkinsus olseni) burden, during a long-term exposure to the harmful alga, Karenia selliformis, and possible interactions. Toxicon 2008, 51, 563-573. [CrossRef] [PubMed]

47. Tillmann, U.; Alpermann, T.L.; da Purificação, R.C.; Krock, B.; Cembella, A. Intra-population clonal variability in allelochemical potency of the toxigenic dinoflagellate Alexandrium tamarense. Harmful Algae 2009, 8, 759-769. [CrossRef]

48. Diener, M.; Erler, K.; Hiller, S.; Christian, B.; Luckas, B. Determination of Paralytic Shellfish Poisoning (PSP) toxins in dietary supplements by application of a new HPLC/FD method. Eur. Food Res. Technol. 2006, 224, 147-151. [CrossRef]

49. Krock, B.; Seguel, C.G.; Cembella, A.D. Toxin profile of Alexandrium catenella from the Chilean coast as determined by liquid chromatography with fluorescence detection and liquid chromatography coupled with tandem mass spectrometry. Harmful Algae 2007, 6, 734-744. [CrossRef]

50. Novas, A.; Barcia, R.; Ramos-Martínez, J.I. After the Prestige oil spill modifications in NO production and other parameters related to the immune response were detected in hemocytes of Mytilus galloprovincialis. Aquat. Toxicol. 2007, 85, 285-290. [CrossRef]

51. Coles, J.; Farley, S.; Pipe, R. Alteration of the immune response of the common marine mussel Mytilus edulis resulting from exposure to cadmium. Dis. Aquat. Organ. 1995, 22, 59-65. [CrossRef]

52. Bradford, M. A rapid and sensitive method for the quantitation of microgram quantities of protein utilizing the principle of protein-dye binding. Anal. Biochem. May 1976, 72, 248-254. [CrossRef]

53. Akaishi, F.M.; St-Jean, S.D.; Bishay, F.; Clarke, J.; Rabitto, I.D.S.; Ribeiro, C.A.D.O. Immunological responses, histopathological finding and disease resistance of blue mussel (Mytilus edulis) exposed to treated and untreated municipal wastewater. Aquat. Toxicol. 2007. [CrossRef] [PubMed]

54. Kuchel, R.P.; Raftos, D.A.; Nair, S. Immunosuppressive effects of environmental stressors on immunological function in Pinctada imbricata. Fish Shellfish Immunol. 2010, 29, 930-936. [CrossRef] [PubMed]

55. Moss, B.; Allam, B. Fluorometric measurement of oxidative burst in lobster hemocytes and inhibiting effect of pathogenic bacteria and hypoxia. J. Shellfish Res. 2006, 25, 1051-1057. [CrossRef]

56. Ritz, C. Toward a unified approach to dose-response modeling in ecotoxicology. Environ. Toxicol. Chem. 2010, 29, 220-229. [CrossRef] [PubMed] 